\title{
The Spread of Buddhism and Peace in Southeast Asia
}

\section{Rajneesh Kumar Gupta*, Alok Kumar Verma}

Central University of Gujarat, Gandhinagar, India

corresponding author: rajneeshkgupta@gmail.com

Received: 14-7-2021; Revised: 3-9-2021; Accepted: 28-10-2021

DOI: $10.31291 / \mathrm{hn} . v 10 \mathrm{i} 2.627$

\begin{abstract}
Buddhism is among the oldest religious traditions of the world. It is based on the life and teachings of Siddharta Gautama. The message of world peace is the greatest contribution of Buddhism to the human civilization. This paper aims to study the spread of Buddhism in the Southeast Asian region and its relations with the ideals of peace in contemporary period. Theoretically paper relies on the post-colonial history writing tradition. It adopts descriptive and analytical method to study the subject matter. Conclusions of the paper are drawn after scrutiny of primary and secondary literatures. A thorough study reveals that Buddhism has a glorious past in the Southeast Asia. The practice of Buddhism in the region was popular even prior to the beginning of recorded history. Different monuments provide tangible evidence, and deep-rooted essence of Buddhism in the socio-cultural practices of the region are intangible testimony to this. Paper argues that inter-religious issues in the region and especially current situation of conflict between people of different faith can be resolved by following philosophy of Buddhism in true sense.
\end{abstract}

Keywords: Buddhism; Peace; Southeast Asia; Inter-religious issues; popular traditions 


\begin{abstract}
Abstrak
Buddhisme adalah salah satu tradisi agama tertua di dunia. Hal ini didasarkan pada kehidupan dan ajaran Siddharta Gautama. Pesan perdamaian dunia adalah kontribusi terbesar agama Buddha bagi peradaban manusia. Artikel ini bertujuan untuk mengkaji penyebaran agama Buddha di kawasan Asia Tenggara dan hubungannya dengan citacita perdamaian pada masa kontemporer. Secara teoritis penelitian bertumpu pada tradisi penulisan sejarah paska kolonial. Analisis penelitian mengadopsi metode deskriptif dan analitis. Kesimpulan dari artikel menunjukkan, bahwa agama Buddha memiliki masa lalu yang gemilang di Asia Tenggara. Praktik agama Buddha di wilayah tersebut sudah populer bahkan sebelum dimulainya sejarah yang tercatat. Monumen yang berbeda memberikan bukti nyata, dan esensi Buddhisme yang mengakar pada praktik sosial budaya di wilayah tersebut adalah kesaksian tak ternilai bagi studi ini. Kajian ini berpendapat bahwa masalah antar-agama di wilayah tersebut dan terutama situasi konflik saat ini antara orang-orang yang berbeda keyakinan dapat diselesaikan dengan mengikuti filosofi agama Buddha dalam arti yang sebenarnya.
\end{abstract}

Kata kunci: Buddhism; Peace; Southeast Asia; Inter-religious issues; popular traditions

\title{
Introduction
}

Buddhism is one of the most important philosophies of the world, developed by Siddhartha Gautama, who lived before 2500 years ago. Over time, Buddhism has spread throughout Asia, Europe and America. After Buddha got enlightenment, he preached his 'dhamma' for nearly 45 years. He visited different places to instill his teachings to the people. It has been argued that his effort in establishing a new religion brought a significant change to a big part of population. However, some scholars also contested that his philosophy posed a political and religious problems (Neelis, 2011). Most of the teachings of the Buddha's life and philosophy are available in Pali language; although it was not ordered chronologically and well-combined. According to Pali sources, the story of the Buddha and his followers is very interesting and important 
Spread of Buddhism and Peace ...

(Dhammika, 1989). In Buddhism, one can purify his life by various methods. Not long after the introduction of Buddhism and its philosophy, millions of people converted to this religion.

Archaeological sources indicate Buddhism was spread to Southeast Asian region back to 3,500 BC through trading relations between India and Southeast Asian countries. Indian religious practices reached to this region through trading activities without any resilience and restrictions (Jha 2016: 213-4). Historical evidences mentioned that the civilizations of Southeast Asia are as old as Egypt, Greece, India, and China (Agrawal, 2015). The region has maintained a long historical record, known as the Golden Age of Southeast Asia.

Buddhism has long been celebrated as the discipline of non-violence and peace. Currently, the practice of Buddhism is popular in different parts of the world and its message of 'world peace' is seen as the basic strand of human civilization; even prosperity and peace are interdependent. Although human civilization is still colored with war and violence, but subsequently peace has been restored with the realization that without peace human civilization will be extinct. In this context, Buddhist teaching of evolving practice of peace and nonviolence from inner sense which ultimately leads to harmony between different socio-cultural groups, religious beliefs and nation-states has always been a promising philosophy (Olson, 2005: pp. 16-17).

Today's human beings trust that peace is a sense of contentment that brings about the conditions around them including feeling safe, successful, or fortunate. Therefore, Buddhist teachings are always inspiring harmony amongst human beings, while at the same time focusing on the inner fellow. 
For example, Buddhism believes that assisting others is a good deal as it generates a source of happiness. The Buddhist philosophy urges for mutual trust, cooperation, self-sacrifices and inner-satisfactions which negates to possibilities of conflicts and violence. In fact, it leads to the essence of peace which is a vital component of our modern society and civilization. Peace has also tremendous ramifications in the animal world. Because of modern world scenario which has been marred by colonialism, two world wars, the cold war, religious confusion and sometimes barbarism, the crumbling down of ethics and morals, and so forth, peace has held the only light. Peace has been restored through agreements and engagements (Panjvani, 2013: pp. 36-37).

Before the era of mass tourism, trade was a major resource by which people from different religions and scriptures came into contact with each other. Although Buddhism is not traditionally a religion that actively seeks convertibility, it nonetheless extends to Southeast Asia. The number of Buddhist merchants in Central Asia in many countries in the 'Middle Ages Religion' kept growing. Buddhist monks also traveled on merchant ships to go on pilgrimage, thus they bring along their religious practices. Evidences indicated that through its propagation, Buddhism has done an important task of bringing peace in the Southeast Asian region (Heine and Prebish, 2003: pp. 21-22). The main reason for the spread of Buddhism in this region was the local interest in the beliefs of Buddhists among foreign traders. Therefore, Buddhism developed organically in these areas. Sometimes, rulers adopted Buddhism to help bring morality to their people, but no one was forced to convert. By making Buddha's message available to the public, people were free to choose what was helpful to them (Ibid: p. 26). This research seeks to examine the spread of Buddhism and peace in Southeast Asia. 
Spread of Buddhism and Peace ...

\section{Theoretical Frameworks}

The paper aims to study the philosophy of Buddhism and its acceptability in the Southeast Asian region through the lens of history. Conventionally, histography has been dominated by two dominant traditions- Marxism and Liberal. The Marxist theory examines social development from 'base' and 'super-structure' model which sees religion as a tool of domination of 'haves' over 'haves not'. The liberal tradition has been largely dominated by the Cambridge pattern in which the eastern world has been branded as primitive and barbaric to justify colonial subjugation of Asian and African regions with the popularly known - the Whitesman Burden Theory. The post-colonial historical writings challenge these notions and try to establish that the countries of the Third World have a glorious past with advancement in technology and spirituality. This paper analyses Buddhism from the perspectives of modern Peace Studies tradition which evolved in Europe in the twentieth century and argues that Buddhism is carrying this since last 2500 years, and therefore it should be regarded as predecessor of the 'Peace Study'.

\section{Method}

This paper mainly relied on historical method by employing descriptive and analytical methods. The sources include different books on Gautama Buddha and Buddhism in Southeast Asia, journals, periodicals, and newspaper articles. Materials are analysed to bring out different aspects of the central theme of the paper. In analytical method, researchers have analyzed incidents/ occurences happened in past and then interpreted them in the present context. In this way, researchers have gone through the available literatures to explore relevant research on the Buddhist philosophy of peace and currently existing and used in contemporary Southeast Asia. 


\section{Literature Review}

There are numerous scholarly works available on the spread of Buddhist's essence of peace. Agrawal (2015) points out that Buddhism is one of the major religions of the world. Its origins can be traced back to the $6^{\text {th }}$ century BC in India sourced from the teachings of Siddhartha Gautama. It later spread to most of Asia region, including China, Korea and Japan. Today, Buddhism has over 300 million followers worldwide. Buddhism teaches individuals to follow the Buddha's path to reach the state of Nirvana. There is no individual God in Buddhism, but a belief in impermanence. One can acquire knowledge through practice, knowledge and mediation.

Ashitsu (1984) argues that the word 'Buddha' means 'awakened', which comes from the Sanskrit root Buddha 'wake up'. A Buddha is a man who is fully awake, as if from a deep sleep, to find that the suffering is over, like a dream. The historical Buddha, though a person like any other, was an extraordinary figure; what he rediscovered was a way that anyone could walk, provided they inclined. His story from the birth to the evolution of Buddhism in India has built a narrative around the contribution of Buddhism to education and literature (Bapat, 1956).

Buddhist vision with extraordinary clarity and depth can serve as a viable solution to the crisis and confusion facing mankind today (Bodhi, 2000). The 'Vision of the Dhamma' refers to the penetrating insight into the true nature of existence that can be observed. His vision of the Dhamma, an intuitive look into the true nature of existence, is a modern guide for the perplexed. He incorporates a deep and rich knowledge of the recorded teachings of the Buddha along with his original understanding of issues of importance to the modern Western mind in 
Spread of Buddhism and Peace ...

exploring topics such as Karma, Nirvana, Bhakti in Buddhism, and the way to get rid of sorrows.

Jayatillake (1962) argues that the concept of peace is contentment, which distinguishes Buddhism from other religions. Peace is the centre of Buddha's religion, which can be known as the Shanti or the peace. In addition to peace, the central tenet of Buddhism also includes nonviolence (Theresa Der-Ian Yen, 2006). He views Buddhist vision of peace in the light of peace studies, and addresses the Buddhist perspective on the causes of violence and way to prevent violence to attain the peace. How Buddhism was spread and how was its impact on the culture of Southeast Asia has also been discussed by Lim (1973). She attempted to make a general scrutiny of the cultural characteristics of Southeast Asian region from the twelfth to the fourteenth centuries, from the early period of Buddhist expansion, with the adequate focus on the Sumatra and Java in Indonesia.

Buddhist philosophy contributed towards the conceptualization of peace, even the Puranas treat Buddha as a heretical teacher of Vedic culture (Joshi, 1970). Buddhism contributed greatly in the Indian art, culture, religion and philosophy. Buddhism focuses not only on individual liberty, but also to liberate socially of men and women. It also contributed to the social harmony and racial integration in ancient India.

Damodar (2007) provides details of the core tenets of Buddhism and their utility to maintain peace in current global order. Besides analyzing Buddha's teachings for global peace, the paper also focuses on the philosophy of Buddhism- its origin, development and spatial spread, organization and functions of Buddhist Council, major sects of Buddhism, and acceptance of Lord Buddha in Hinduism as an incarnation of Lord Vishnu. Author argues that Buddhist teachings 
inspire practical techniques to manage anger, control desire, and build harmonious relationships. It points out that the world is full of violence and corruption, thus human beings seek comfort from the spiritual path and teachings of non-violence, contentment, compassion, generosity of spirit and peace of mind. Buddhism teaches us to cultivate peace from within our hearts and to work to remove the sufferings of all living beings. The attainment of peace at the local, national or universal level is possible only by applying Buddhism in our daily life.

There are different interpretations of central teachings of Buddhism (Hamilton, 2000). Hamilton seeks to illustrate the core of Buddha's teaching to the whole world. He proposes the new important interpretations for all fundamental keys of Buddha's thought, and discusses the draw out reasons why certain ambiguous teaching were given at all and also suggested to focus on over all life of Buddha.

The wide range of literature above indicates that there are ample studies on the origin of Buddhism, its spread in different parts of the world and its glorious history of Southeast Asia. However, these studies are mostly focused on philosophical basis of Buddhism and the presence of this tradition in Southeast Asia. There has been limited research on the presence of Buddhism and its impact on the spread of peace in Southeast Asia from the perspectives of modern 'Peace Studies'. The novelty of this paper is that, it seeks to explore possibilities of applying principles of Buddhism to bring solutions of the issues of inter-religious conflicts in other parts of the world.

\section{Result and Discussion}

History of Buddhism in Southeast Asia 
Spread of Buddhism and Peace ...

Historically, Buddha's teachings were divided into two fundamental orders namely, the 'Mahayana and the Theravada'. Theravada is known as the original form of Buddhism and Mahayana is known as the created form of Buddhism (Laumakis, 2008: pp. 190-99). Mahayana Buddhism is practiced in Tibet, China, Taiwan, Japan, Korea and Mongolia. Mahayana Buddhism is not a single tradition, but it is a collection of Buddhist traditions, like: Zen Buddhism, Pure Land Buddhism, and Tibetan Buddhism. Theravada Buddhist traditions are adhered in most of the South Asian countries such as: Burma, Cambodia, Thailand, and Laos.

In Southeast Asia, Hinduism and Buddhism were practiced in the first century BC (Jha, 2016: pp. 213-16). In Indonesia, a center of Buddhist education existed in the $7^{\text {th }}$ century established by a Chinese traveler. Borobudur, the largest Buddhist temple in Indonesia was built in the Central Java in the $9^{\text {th }}$ century. However, in the $13^{\text {th }}$ century, the practice of Buddhism declined in the region due to the collapse of Srivijaya's kingdom. Over the period of time, the beauty of Borobudur receded and it started to be abandoned. Situated in an area of active volcanoes, Borobudur remained submerged under the volcanic ash and forest growth for tcentruies. Later in the $19^{\text {th }}$ century, British explorers discovered it and rebuilt the monument that today is seen as a symbol of a glorious past of Buddhism in the region (Braun, 2009: p. 37).

Angkor Wat of Cambodia is another huge temple complex of Buddhism. The temple was constructed by the Khmer people around the $12^{\text {th }}$ century. The temple is a testimonial for Buddhism popularity in the region those days. It is interesting to note that initially the temple was dedicated to the Hindu deity Vishnu. As Khmer kings adopted 'Mahayana Buddhism' the Angkor Wat temple became a Buddhist 
pilgrimage. The 'Theravada Buddhism' was introduced in region by missionary monks of Sri Lanka in the $13^{\text {th }}$ century. It reached Cambodia from Laos and Thailand and received a patronage of Khmer dynasty. Today, Angkor Wat temple is a major centre of 'Theravada Buddhism'. It is noteworthy that some people have a faith that Buddha himself visited Myanmar. There are some archaeological evidences of Buddhism in Southern Myanmar dated back to the $4^{\text {th }}$ century. Nevertheless, most of Myanmar people adopted Buddhism in the middle of the $11^{\text {th }}$ century and made it their state religion (McGovern, 1919: pp. 17-18).

Southeast Asia is geographically and religiously divided between major regions. It encompasses Buddhism on a large scale. Sunni Muslims in this region represent the majority faith with estimates of over 40 percent. Buddhism (mainly Theravada Buddhism) comes the second place, followed by Christianity in Southeast Asian countries, with the majority of its members living in the Philippines. Almost all countries in Southeast Asia are religiously pluralistic. Ethnicity is an issue in religious conflict here because in Southeast Asia religious identity is often inseparable from ethnic identity (Kosuta, 2017: p. 24).

Buddhism has a deep rooted history in the Southeast Asian region. Today, Buddhism is followed by minority of Southeast Asian people , except Singapore where Buddhism is the most widely practiced religion.

\section{Inter-religious Issues in Southeast Asia}

The growing tension between different socio-religious communities and fundamentalism has emerged a major challenge for peace and security in the present global order, and Southeast Asia is not an exception to it. Amid such increasing tension, implementing rules of common law will 
Spread of Buddhism and Peace ...

not be sufficient for any country. In such stressful time, a deep understanding of Buddhist nationalist discourse can reduce complaints to a great extent. In this way, Buddhism is important for improving mutual coexistence in the region. As such, Buddha's emphasis on the moral duty of a ruler inspired Emperor Ashoka in the third century BCE 'to use public power to improve the welfare of the public' (Bhikkhu, 2012: pp. 36-39).

Similarly, with a shining instance of this principle, Emperor Ashoka resolved to live in accordance with Dhamma and to serve the entire humanity. Hence, Buddha must be regarded as a pioneer social reformer of ancient history. He was in total opposition to the prevailing caste system in India and preached for the equality of the people, improved the socio-economic conditions of people and considered the importance of the more equitable distribution of wealth between rich and poor. Further, he should also be considered a forerunner intellectual of gender equality as equal opportunities were provided to women in the Buddhist institutions. The principles of welfare state and humanist administration can also be traced in the philosophy of Buddha. He recommended for the welfare of people, incorporation of humanism into government and administration, and a principle that a society should be run not with greed but with consideration and compassion for the people (Berzin, 1996: pp. 15-16).

Theravada Buddhism was the organizing principle of pre-modern states in many parts of the South and Southeast Asia until the colonial subjugation of these regions in the $19^{\text {th }}$ century. Prior to colonialism, the monarchical states in Thailand, Myanmar and Sri Lanka drew their legitimacy prominently by basing their rule on the Dhamma, the teachings of the Buddha and the support of Buddhist monks. Thus 
Monarchus was interested in supporting the nuns physically and politically and played the role of defenders and promoters of Buddhism. Buddhism was a vital in establishing legitimacy of state. It also played crucial role in the various spheres of pre-colonial Burman and Sinhalese societies- culture, language, law, education and so on. Therefore, Buddhism became a major component of modern nationalist selfconcepts (Stein, 2014: pp. 2-3).

Transformative influences still exist in modern conceptions of nationalism brought about by Western education in Southeast Asian countries. Buddhism has played a historical role in legitimizing the rights of the states and in some countries its custom, culture and traditions are still alive. Despite the relentless efforts of colonial powers, many traditional institutions remained unchanged. The colonial encroachment in the region has challenged the religious legitimacy of the state. In order to secure sovereignty in an expanding system of nation-states, the ruling elites saw the need to build a modern states by dropping old socio-cultural practices and symbols of nation. However, modernization must not bee seen contrary to Buddhism, 'the Southeast Asian nation can be given a new identity through the 'teachings of Buddhism', and a great state can be created' (Iselin, 2015: p. 2).

The emergence of modern Buddhist nations has expanded the traditional relationship between the state and Buddhism in Southeast Asia to include a third powerful element. Thus, the concepts of the state, religion and nation are interlinked and interrelated. Any perspectives on threats or opportunities should be seen in totality. With the end of colonialism, monks are continuing their mission to defend Buddhism against new threats. They look modern state machinery with suspicion. This is particularly true in Sri Lanka and Myanmar, where a group of monks 
Spread of Buddhism and Peace ...

tried to restore the traditional monarchy. Meanwhile, the majority of monks have played an assertive and independent role in protecting the nation and religion. This has resulted in increasing pressure on newly independent states to affirm and encourage Buddhism practices and institutions. In certain cases, politically engaged monks have also been critical on religious minority rights for non-Buddhist minorities. Such activism gave rise to state policies, which has been criticized for being exclusionary and discriminatory against religious minorities. This unique occurrence became a distinct identity of Buddhism in the Southeast Asian region (Schober, 1995: pp. 12-15).

Thus, Buddhism has served to reinforce the state's identity as well as 'the political, economic, military and cultural dominance of Burman and Sinhala ethnic majorities in both colonial Myanmar and Sri Lanka'. It is quite similar case of Thailand, except the role of monks in this country was not as much of importance. Nevertheless, Buddhism helped fortify state sovereignty including territories in northern Thailand settled by non-Buddhist groups such as hill tribes. These are the main features of Buddhism (Ibid).

Therefore, mutual tension in this area must not be overlooked. Undoubtedly, the 'rule of law' is essential requirement for the safety and security of the state and its people. The religious conflicts in certain areas of Myanmar has been a concern not only for the Southeast Asian region but also at global scale. To bring any fruitful solution, authorities needs to rely on mutual negotiations and politically active clerics can be of great help to resolve the problem. In fact, there has been various official and unofficial discussions involving Buddhist and Muslim religious leaders to resolve the matters of conflict and violence. Many of these dialogues were supported by international agencies, local 
governments, NGOs, and so on. There has been various dialogues and joint activities in faith groups as well as training of religious leaders including monks for conflict prevention and resolution. In this way, mainly Buddhism has played a major role in organizing such incidents (Stein, 2014: pp. 3-4).

\section{Popular Traditions in Southeast Asian Countries}

Muslim and Buddhism are major religions in Southeast Asia, followed by Christianity. Immediate neighbours are the first account witness of any happening to a country, followed by other distant fellows. This is true in terms of propagation process of any religion or sect- known as the spatial spread in cultural geography. In this way, world communities share many different cultural traits. Buddhism is also a cultural and religious phenomenon with its century old's presence in Southeast Asia making deep impression in the different walks of life in this region. It gives rise to new forms of cultural and religious beliefs affecting the field of study of geographical factors and the attitudes of people of any community (Brown, 2001: pp. 7-8). The world's major religions are specifically associated with racial groups, geographical boundaries, cultural identities, political systems, and way of living. For example, modern Thailand is incomplete without Buddhism, Hindu traditions are deep-rooted in Nepal and India, the British culture is essentially linked with Christianity. However, religious practices cannot be confined to political boundaries. Buddhism is the best example of this because, at present, it has spread very rapidly in the western world (Park, 2004: p. $11)$.

Buddhism is a religious practice as well as a philosophy. Philosophy is a discipline, which encompasses the process of investigation, interpretation, and development of ideas. It deals with common wisdom 
Spread of Buddhism and Peace ...

of values and reality. The use of discipline in Buddhism is based on the important ideas and concepts of the Buddha, moral obligation, knowledge, reason, issues, problems, logic, ethics, conceptual analysis, and a theoretical aspect. In Buddhism, the emphasis has been placed on reasoning and reasoning. It creates an atmosphere of equality and brotherhood in society. Buddhism includes all traditions based on the teachings of the Buddha (Berzin, 1996: pp. 6-19).

Buddhism is divided into two main traditions, namely Theravada and Mahayana. Theravada means 'teaching of the elders'. The origins of Theravada tradition are closely associated with the history of Sri Lanka. Theravada Buddhism is also referred to as Southern Buddhism. It has 150 million followers, living in Sri Lanka, Myanmar, Cambodia, Laos, and Thailand. Theravadins follow practices passed by senior monks since the time of the Buddha, such as living in the forests and meditating. The goal in Theravada Buddhism is an Arhat, a person, free from grief. It is also known as the Southern School. Mahayana Buddhism is one of the other and larger traditions of Buddhism. It is practiced mainly in East Asia, such as China, Japan, Korea, and Tibet.

Presently, Theravada Buddhism is the most popular tradition in Southeast Asian countries. Therefore, the actual practices of Buddhism in Southeast Asian countries are still alive today. The main basis of the teachings of Buddhism is the "Four Noble Truth and the Noble Eightfold Path'. Theravada Buddhism of Southeast Asia is unlike other great historical religions; it defines the moral perfection of Buddhism and the ideal goal of ultimate self-transformation, as well as the means to achieve them. Therefore, Buddhism in South-East Asia provides equal rights and resources for all. With this, people can face the problems of life as well as the justification to vindicate all the activities of the world. 
Such goals have been accepted in the writings of the Pali canon, a discourse of Theravada Buddhism (Stein, 2014: pp. 4-9).

Theravada Buddhism is in the strongest position in Sri Lanka, Thailand, and Myanmar in the ancient period. Therefore, Sri Lankan monks greatly helped to revive Theravada Buddhism in Southeast Asian countries (Bali, Indonesia, and Malaysia), where it gradually came to an end by the end of the fifteenth century. In Indonesia, Buddhism is officially considered as one of the six state religions. The other five are Islam, Protestantism, Catholic, Hinduism, and Konghucu. In Thailand, the Buddhist monastic community has supreme patriarchy and a council of elders, who take responsibility for maintaining the purity of this tradition. It has two types of monastic communities, one inhabiting forests, and the other living in villages. There is also a Buddhist university for monks. It is mainly opened for Buddhist teachings.

Unfortunately, Myanmar military rule ruthlessly destroyed the monasteries where disgruntled people lived, especially in the north of the country. Now, the government is providing huge money supports to the monks to win their support and trust. The country has a long tradition of equal thrust on meditation and education, particularly the 'Abhidhamma' system of Buddhist psychology, metaphysics, and ethics (McGovern, 1919). There are many meditation institutes where monks and teachers train people in basic meditation practices. However, on many occasion, Buddhist monks have shown their anger and unsatisfaction towards the military regime in Myanmar. For instance, in 2007, the 'saffron revolution' caused the colorful robes of the spiritual leaders of Myanmar to fall before the bullets of Myanmar's powerful army. However, today, the images emanating from Myanmar are certainly different from about a decade ago. Now, the monks in 
Spread of Buddhism and Peace ...

Myanmar are demonstrating in defense of Buddhism, which has been directed against the country's minority Muslim communities (Taylor, 1987: pp. 6-9).

Similarly, mutual tensions are also increasing in several Southeastern countries. "In the south of Thailand, where the government is engaged in a century of conflict with the 'Malay Muslim Rebels', the monks are caught in conflict. Hence, the army has entered some temples, and rumors are circulating socially to "military monks"” (Stein, 2014: p. 1). Such developments are opposite to the concept of Buddhism, which preaches for non-violence and considers killing of any living as a sin. These types of developments predict a growing rift between Buddhist and Muslim communities in the most populous Theravada BuddhistMuslim countries, which leads to such a sense of development. This incident calls for an understanding of Buddhist nationalist discourses, which claim that the state belongs to a majority nation, be it Burman, Sinhalese, or Thai, this nation would naturally be a Buddhist nation. Only, if the driving force behind these discourses is understood can the growing interrelated tensions in South and Southeast Asia are addressed constructively (Hipsher, 2011: pp. 6-15).

\section{Present Circumstances of Buddhism in Southeast Asia}

The historical development of Buddhism has been full of complexities. Buddhism is not meant to be merely a philosophy, but also a defined doctrine and a set of rituals that includes a whole range of human activities, including literature and art. The influence of Buddhist ideas on social institutions creates an important build-up of mutual relationships. Today, Buddhism has spread to all parts of Asia, extending from Afghanistan in west, Java in the southeast, Japan, Korea, and China-Mongolia in the northeast. Southeast Asia comprises 10 
countries: Indonesia, Malaysia, Thailand, Philippines, Myanmar, Laos, Cambodia, Singapore, Vietnam and Brunei. Islam and Buddhism are the two most popular religions of this region.

The most notable fact on the spread of Buddhism in Southeast Asia is the way of its arrival in the region in which people took part willingly without fear or greed. Buddhism reached here peacefully as a missionary or brought by the sailors and merchants. Not long after, Buddhist literature gradually reached Asian countries. Buddhist missionaries and scholars, who were also tireless travelers, did important works in the affairs of the Southeast Asian states. More important for the development of Southeast Asian states was the fact that Buddhism became a demonstrative system of beliefs operating in India along with Hinduism. The role of Buddhism as a magnetic force was growing on average much higher than that of Hinduism. The main reason for this was the main principle of Buddhism.

When Buddhism arrived in Asia, the multiplicity of beliefs and practices was in a full swing. Buddhism and Hinduism made this stream of diverse beliefs a part of their respective religions and strengthened their hold over them. Simultaneously, Mahayana and Theravada were undergoing popularization in Buddhism as a sect. These were conditions that continued Buddhism in Southeast Asia, even in India that declined in the tenth and eleventh centuries. Buddhism acquired more popularity and acceptance in the societies of Ceylon, Burma, Thailand, and Cambodia. Countries, that to date consider Buddhism as the core of their social ethos and where the circle of Buddhist customs focuses on social relationships even at the rural level. These are the main features of Buddhism, which remain today (Banerjee, 1990: pp. 32-33). 
Spread of Buddhism and Peace ...

\section{Influence of Buddhism and Peace in Southeast Asia}

Peace as a concept has a variety of understandings in different cultures. It can be said to exist when people resolve their differences or work together without any conflict. Scholars would claim pithily that peace is not just the absence of war (Galtung, 1969). The term peace has been articulated almost as frequently as terms like truth, beauty, and love. It has been argued by scholars that the concept of peace has emerged since the birth of humanity and is often linked to the Chinese, Indian, Arabic and other cultures. The concept of peace is not so much concerned with how certain individuals or leagues conceptualized the realization of an eternal dream, the investigation of peace, and how to change the world in socio-political institutions.

Serious academic engagement with the concept of peace began around the 1960s (Matsuo, 2007). In the 1960s', Galtung articulated the idea of peace and violence in the context of indirect or structural violence. According to Grewal, such an attempt by Galtung was a direct test to establish ideas about the nature of peace (Grewal, 2003). In conceptualizing the term 'peace' and to measure its complexity, Galtung employed two perspectives such as peace value and peace sphere. Galtung argued that "an important task in peace research has always been and always be the exploration of the concept of peace" (Galtung, 1981).

According to Galtung, the following are the main three principles of the idea of peace. "The term peace will be used for social goals at least verbally agreed to be many, if not necessarily be the most. These social goals may be complex and difficult, but not impossible to attain. The statement of peace is the absence of violence will be retained as valid" (Galtung, 1969). The third conviction makes it clear that the concept of 
peace and violence are interlinked concepts because peace can be achieved in the absence of war (Ibid). Coming to the Indian context, it could be seen that in contemporary India, violence and conflict take place in many parts of Indian society such as religious, political and economic conflicts and violence against human rights (Matsuo, 2007).

Though almost all the religions of the world believe in the ideals of peace, Buddhism views it is the first and foremost essence of life. Peace is the most important part of Buddhism. Peace in Buddhism can be traced to Buddha's teachings and his lifestyle. Buddha's ideals of peace are based on his teachings and his lifestyle. Buddha's teaching and lifestyle are not only very simple but also very practical. In Buddha's philosophy, peace is a way of achieving salvation. A person has to follow certain rules of morality to attain salvation. Buddha has focused on certain moral principles that are very much essential for leading a meaningful and disciplined life that will guide one towards Nirvana. During Buddha's time, the followers of Buddha were leading a very moral, truthful, and peaceful life which was based on freedom, justice, and love. Buddha also focused on the requirement of fellow felineness among people and the communal service in human life. Buddha also focused on equality among people and justice in the society. As Haynes observes,

"Peace is one of the important aspects of any developed country. Without peace, no country can develop, whether economically, socially or politically. ...Peace is essential for social harmony, economic equality, and political phenomena. The spiritual and religious leaders like Buddha, Jesus, Gandhi, and the Dalai Lama were lovers of peace and they considered it an essential part for any society. There are some people, who interact with those who may dislike and be jealous of them, but still, they try to maintain peace. Many philosophical, religious, and cultural traditions have 
Spread of Buddhism and Peace ...

mentioned the peace in its positive and negative sense". (Haynes, 2009: Pp. 52-75)

Without peace, no country can progress in today's world scenario. Peace can be conceptualized in terms of political stability, economic security, social equality and justice and the sharing of love among human beings. 'Love your neighbour' should be the marking principle of the countries of the world, which will help in the establishment of peace among the comity of nations.

Buddha had never believed or felt that he was founding or declaring a new religion. Buddha did not start a new religion. It stood as a reaction to Hinduism. He gave new light on the old ideals of the Indo-Aryan civilization. Buddhism focused on high moral principles and strict ethical ideals. Certain values that Buddhism focused on were very much unknown to the people of Indo-Aryan civilization. The moral and spiritual ideals, as well as ideals of Ahimsa, Moksha, Karma, and rebirths, were completely unknown to pre-Upanishadic Vedic religion or Indo-Aryan civilization (Joshi, 1970: pp. 1-35).

One of the significant codes in Buddhism is the principle of Karma. The principle of Karma is one of the four pillars of Indian wisdom. It believes that the connectedness that exists among the whole being of things and the interdependence of human life. Karma is a synonymous to a sense of responsibility in life. It focuses on the sense of kindness and consideration for others. It helps them understand the essence of peace in their Karma as well as their interconnectedness to the outer world. Buddhists mostly prefer peace in every sector of society such as in schools, families, or the environment (Der-Ian Yeh, 2006: pp. 91112). 
The development of the philanthropic temperament and kindness in people are very much crucial to the ascertaining of peace among various people, families, and countries of the world. Applying the ideals of peace to the contemporary world scenario, Der-Ian Yeh states that the Buddhist interpretation of establishing peace is possible only when it starts from person to person, rather than, through discussions between the world powerful countries on the table. To establish peace, efforts should continue, until it is established (Der-Ian Yeh, 2006: pp. 91-112). As mentioned above, peace in Indian philosophy and religion has been present from an ancient period even before the advent of Buddhism. Buddhism heightened and polished the notion of peace. Jayatillake states that another aspect of these practices of compassion on the part of Buddhism, in fact, those other philosophical traditions in India (Jayatillake, 1962: pp. 1-16).

Buddha's conviction of spreading peace in the world is quite praiseworthy. His methods of spreading peace are also quite appealing. Buddha inculcated a sense of missionary zeal among his followers to spread the message of peace in various corners of the globe. Buddha had realized that it is peace that will only hold the world for a long run. Violence will only destroy the world. His early goal was to teach people the essence of peace in different parts of the world and different corners of India. Even after Buddha's period, this method of preaching peace was more popularized. This was indeed a very good method of making people aware of peace and certitude in life. Buddhism also preaches people about self-restraint and discipline. Buddhist monks through their self-restrained and controlled life gave the message of the importance of discipline in life. Buddha sent the message of peace to the world through missionary monks (Dharmakosajarm, 2000, pp. 1-10). 
Spread of Buddhism and Peace ...

After Buddha's death, diverse opinions arose among different Buddhist scholars about the understanding and interpretation of Buddhist texts. However, some of the historical records pointed out that both adherents of Mahayana and Theravada Buddhism were sitting side by side and studying the Buddhist scriptures in the same monastery. In the world conference of Buddhists, Mahayanists and Theravadas came together, although they had a difference in their opinions. Though the scholars on Buddhism disagree on the interpretation of Buddhist texts, they all agree on the Buddhist essence of peace. So, the notion of peace is a very significant contribution of Buddhism, especially in the Southeast Asian region (Core, 1973: pp. 13-14).

Buddhism not only tried to bring about a transformation in the human mind and soul through the preaching of its ideals and its focus on peace in human life. It also tried to bring about a social and political transformation in the society. Buddhism believes in an egalitarian society where every man in the society has a say and equity in the status. At the outset, it must be made clear that Buddhism focused on a simple life with no materialistic desire. Followers of Buddha emphasize the simple and truthful life to achieve enlightenment. From the very beginning of the advent of Buddhism, it brought about social, political, and economic changes in the society of that period (Olson, 2005: pp. 68$70)$.

The social transformation was to be marked in all spheres of the society ranging from a small village to a kingdom. The political modification included the changes in the structures of the village administrations to the administrations of the kingdoms. In the economic sphere, Buddhism brought changes in the agricultural patterns. It focused on agriculture which was considered the backbone of the economy. The use of iron was 
prevalent during this period which greatly facilitated agricultural activity. Trade was also focused during this period. A trading community had emerged during Buddha's period where people develop their skills (Core, 1973: pp. 22-23).

In addition to these changes in the social, political, and economic spheres, significant changes were also found in the spheres of language and literature. As it is a very well-known fact that Buddhism had touched a new height during the reign of Asoka. Asoka had sent his son Mahendra and daughter Sanghamitra to preach Buddhism in Sinhala (present-day Sri Lanka), different parts of South and East Asian countries. During Asoka's period, the Pali language was of dominance. During this period, Buddhism was spread through the Pali language. Many Buddhist works of literature were also written in Pali during this period (Schober, 1995: pp. 15-16).

At different phases of its history and development, Buddhism brought about changes in the social, political, economic, linguistic, and literary spheres of the society. Both the Hinayana and Mahayana Buddhists tried to bring the transformation in the society in different ways. As Jayasuriya observes, Buddha's teachings affected every sector of society whether it is social, political, or economic. Therefore, Buddhism had shown extraordinary efforts to change the social and geographical conditions of the people in the Southeast Asian reason (Jayasuriya, 2008: pp. 41-44).

\section{Conclusion}

This paper has analyzed the basic tenets of Buddhism and the spread of Buddhist tradition in the Southeast Asian region through the lens of history. It has also provided a brief status of the social and political 
Spread of Buddhism and Peace ...

relations towards the goal of Buddha's social unity and message of peace in Southeast Asian region. Buddhism has enlightened every sphere of human life-social, political, economic, psychological, religious lives. Buddha's philosophy of peace is one of the important mediums, through the human civilization we can attain the goal of world peace.

Although human beings tend to incite wars, Buddha stressed on inner peace of human body and mind which leads to the co-existence in the society and among the nations. Often time, people search for peace in the wrong ways. In the prevailing situations where materialistic thoughts dominate, people consider that wealth and money are sources of happiness. The teachings of Buddha take us into the spiritual satisfaction in which extreme pleasures can be attained without struggling for attainment of physical affluence.

When the teaching of Lord Buddha is followed comprehensively, Buddhism can become a platform to bring peace and prosperity in the society. On the contrary, misinterpretations of the teachings of Buddha and non-compliance to the basic essence of Buddhist philosophynonviolence can lead to the deviations from the path of peace. Recent conflicts in some parts of Southeast Asia among Buddhist,s Rohingya Muslims and people of other faiths are completely against the preaching of Buddhism. Buddha believed that despite different religion, caste, region, and colour of all human beings, peace is universal and one of the main principles to be followed by every individual. Thus, the Buddhist message of peace provides us a solution to the present conflict between countries and communities. In this way, Buddha's philosophy of peace must be stressed and popularized in Southeast Asian region. 


\section{References}

Agrawal, R. (2015). Buddhism. In Athyal, J.M (ed). Religions in Southeast Asia: An Encyclopaedia of Faiths and Cultures. Santa Barbara: ABC-CLIO. 22-26.

Ashitsu, Z. (1894). The Fundamental Teachings of Buddhism. The Monist, 4(2), 163-175.

Banerjee, A. C. (1990). Hinayana and Mahayana: A Broad Outline. Bulletin of Tibetology, 26(1), 23-25.

Bapat, P. V. (1956). 2500 Years of Buddhism. New Delhi: Publications Division.

Berzin, A. (1996). The Current Situation of Buddhism in the World. Cairo: Cairo University, Center for Asian Studies.

Bhikkhu, J. (2012). Theravada and Mahayana: Parallels Connections and Unifying Concepts. Academic papers Presented at the $2^{\text {nd }}$ IABU Conference Mahachlalongkornraja Vidyalaya University, Main Campus Wang Noi, Ayutthaya, Thailand.

Bodhi, B. (2000). The Vision of Dhamma: Buddhist Writings of Nyanaponika Thera. Washington: Pariyatti Publication.

Braun, E. (2009). Local and Translocal in the Study of Theravada Buddhism and Modernity. Religion Compass, 3(6), 935-950.

Bräunlein, J. P. (2014). Spirits in and of Southeast Asia's Modernity an Overview. In Gottowik, V. (ed.). Dynamics of Religion in Southeast Asia: Magic and Modernity. Amsterdam: Amsterdam University Press. 33-54.

Butwell, R. (1969). U Nu of Burma (Second edition). Stanford: Stanford University Press.

Damodar, J. (2007). Buddhism and Global Peace: Perspectives on Cultural Geography. The Third Pole: Journal of Geography Education, 5(7), 28-36.

Der-Ian Yeh, T. (2006). The Way to Peace: A Buddhist Perspective. International Journal of Peace Studies, 11 (1), 91-112.

Dhammika, S. (1989). Daily Readings from the Buddha's Words of Wisdom. Singapore: Buddha Dhamma Mandala Society Publications.

Dharmakosajarm, P. (2009). Buddhist Approach to Political Conflict and Peace Development. Thailand: UNDV Conference.

Heritage of Nusantara: 
Spread of Buddhism and Peace ...

Galtung, J. (1969). Violence, Peace, and Peace Research. Journal of Peace Research, 6(3), 167-191.

Galtung, J. (1981). Social Cosmology and the Concept of Peace. Journal of Peace Research, 18(2), 183-99.

Grewal, B. S. (2003). Johan Galtung: Positive and Negative Peace.

Hamilton, Sue (2000). Early Buddhism: A New Approach. New York: Routledge.

Haynes, J. (2009). Conflict, Conflict Resolution, and Peace- Building: The Role of Religion in Mozambique, Nigeria and Cambodia. Commonwealth and Comparative Politics, 47 (1), 52-75.

Heine, S., and Prebish, C. S. (2003). Buddhism in the Modern World: Adaptations of an Ancient Tradition. New York: Oxford University Press.

Hipsher, H. S. (2011). The Impact of Theravada Buddhist Values on Work Practices in South Asia. SIU Journal of Management, 1 (1), 76-100.

Iselin, F. (2015). The Rise of Buddhism-Muslims Conflict in Asia and Possibilities for Transformation. Oslo: NOREF Policy Brief.

Jayasuriya, L. (2008). Buddhism, Politics, and Statecraft. International Journal of Buddhist Thought and Culture, 11, 41-74.

Jayatillake, K. N. (1962). Buddhism and Peace. Kandy (Sri Lanka): Buddhist Publication Society.

Jha, G.K. (2016). Indonesian Cultural System and Undercurrent. Heritage of Nusantara- Indonesian Journal of Religious Literature and Heritage, 5(2), 212-29.

Joshi, L. M. (1970). Brahmanism, Buddhism, and Hinduism: An Essay on their Origin and Interactions. Kandy (Sri Lanka): Buddhist Publication Society.

Kosuta, M. (2017). Postcolonial Religious Conflict in Southeast Asia. Contemporary Postcolonial Asia, 22(1), 24-30.

Laumakis, S.J. (2008). An Introduction to Buddhist Philosophy. Cambridge: Cambridge University Press.

Lim, A.R. (1973). Buddhism in Early Southeast Asia: A Contribution to the Study of Culture Change. Asian Studies, 11(1), 75-97.

Mccargo, D. (2004). Buddhism, Democracy, and Identity in Thailand. Democratization, 11(4), 155-170. 
McGovern, M. (1919). Notes on Mahayana Buddhism. The Monist, 29 (2), 238-258.

Neelis, J. (2011). Early Buddhist Transmission and Trade Networks: Mobility and Exchange within and beyond the Northwestern Borderlands of South Asia. Leiden/Boston: Brill.

Olson, C. (2005). The Different Paths of Buddhism: A Narrative Historical Introduction. London: Rutgers University Press.

Panjvani, C. (2013). Buddhism: A Philosophical Approach. Peterborough: Broadview Press.

Park, C. (2004). Religion and Geography. London: Routledge Publication.

Robinson, R. Rodan, G. \& Hewison, K. (1993). Southeast Asia in the 1990s: Authoritarianism, Democracy and Capitalism. USA: Allen, and Unwin.

Schober, J. (1995). The Theravada Buddhist Engagement with Modernity in Southeast Asia: Whither the Social Paradigm of the Galactic Polity?, Journal of Southeast Asian Studies, 26(2), 307325 .

Smith, B. (1978). Religion and Legitimation of Power in Thailand. Laos and Burma, Chambersburg, PA: ANIMA Books.

Smith, D. E. (1965). Religion and Politics in Burma. Princeton: Princeton University Press.

Smith, M. (1991). Burma: Insurgency and the Politics of Ethnicity, London: Zed Books.

Stein, S. (2014). Interreligious Tension in South and Southeast Asia. CCS Analyses in Security Policy, 148, 1-4.

Swearer, D. K. (2010). The Buddhist World of Southeast Asia. New York: State University of New York Press.

Taylor, R. (1987). The State in Burma. London: C. Hurst Publication. 